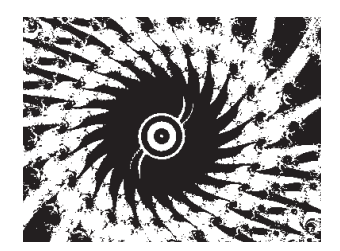

doi:10.5559/di.21.4.01

\title{
HRVATSKI MEDIJSKI SUSTAV IZMEĐU REFLEKSIVNE MODERNIZACIJE I MEDIJATIZACIJE: SOCIETALNA I INSTITUCIONALNA ANALIZA
}

Paško BILIĆ

Institut za međunarodne odnose, Zagreb

UDK: $316.77: 316.4(497.5)$

Pregledni rad

Primljeno: 21. 10. 2011.

U zadnja dva desetljeća hrvatsko je društvo prolazilo kroz važnu društvenu transformaciju i promjene u svim aspektima društvenoga života. U tom je kontekstu medijski i komunikacijski sustav rijetko promatran integrativno ili kao središnji dio tih društvenih procesa. Cili je rada analizirati društvene i institucionalne promjene medijskoga sustava, odnosno društveno-političke promjene i promjene tržišta i tehnološkog razvoja, kroz prizmu dviju suvremenih društvenih metateorija: refleksivnu modernizaciju i medijatizaciju. U tome se kontekstu iznose podaci o brojnosti mediija, strukturi vlasništva i dosezima u publikama te analize službenih dokumenata u pregovorima s Europskom unijom. Pojedine ključne promjene medijskoga sustava koje se analiziraju jesu institucionalne promjene javnoga servisa, liberalizacija i privatizacija tržišta kao pomicanje sfera javnoga i privatnoga, promjena paradigme dominantnoga medijskog sadržaja i, kao posljedica, komercijalizacija medijskog prostora, utjecaji Europske unije te povećana uloga interneta i novih medija u medijskom i komunikacijskom sustavu. Upravljačke odluke u medijskom sustavu proizvode nenamjeravane posljedice, dok se istodobno društveni procesi prilagođuju medijima, koji zauzimaju sve važniju društvenu ulogu. Zbog takvih promiena mijenja se sustav koordinata nacionalnoga sustava, koji je sada potpuno otvoren transnacionalnim procesima.

Ključne riječi: refleksivna modernizacija, medijatizacija, javni servis, liberalizacija tržišta, Europska unija

Paško Bilić, Instituł za međunarodne odnose, Odjel za kulturu i komunikacije, Li. F. Vukotinovića 2, 10000 Zagreb, Hrvatska. E-mail: pasko@irmo.hr 
U ovom radu ${ }^{1}$ govori se o suvremenim procesima koji se odvijaju u medijskom i komunikacijskom sustavu, ali i u društvu i kulturi u cjelini. Ona nužno kreće iz nacionalnog ishodišta, jer sustav možemo definirati prije svega u okviru teritorijalnih granica nacionalne države, unutar kojih vrijede specifične zakonske regulative te jezične i druge kulturne odrednice. Pod medijskim sustavom razumijevamo državne institucije usmjerene prema uređivanju medija i njihova djelovanja, odnosno formalno-pravnoga funkcioniranja, a u prvom redu one medijske institucije (javne i komercijalne) koje se bave proizvodnjom medijskoga sadržaja na hrvatskom medijskom tržištu. Istodobno pokušavamo utvrditi koordinate procesa i promjena koje izmiču nacionalnom gledištu i koje otvaraju nacionalni prostor složenom amalgamu vanjskih i unutarnjih utjecaja. Rad se temelji na nizu pojedinačnih istraživanja medijskoga sustava, ali pokušava uspostaviti teorijski okvir unutar kojeg se sve te, katkada previše složene i specifično problematične, pojave mogu promatrati kao dio sveobuhvatnoga procesa. Ovaj proces nije u cjelini empirijski mjerljiv ni potpuno kvantitativno izraziv, on nije u cjelini ni vođen racionalnim medijskim politikama ili normativnim pretpostavkama, ali u teorijskom smislu omogućuje nam uspostavljanje jedinstvenoga referentnog okvira, unutar kojeg možemo razumjeti odnose među institucijama i složenim procesima. Ti se procesi u globalnom kontekstu odvijaju posvuda, ali poprimaju specifične institucionalne karakteristike i društvene oblike te imaju različite intenzitete kao i različite društvene i kulturne posljedice $u$ nacionalnim okvirima. Radom se na taj način pokušava odgovoriti na niz povezanih pitanja, kao što su: kako možemo zajednički promatrati tako složene i naizgled odvojene procese, poput, primjerice, koncentracije vlasništva u tiskanim medijima $\mathrm{i}$ istodobno bujanje komunikacije kroz društvene medije (eng. social media)? Sto znači promijenjeni odnos između javnih i komercijalnih televizija u nacionalnom medijskom prostoru? Kakav je odnos između pristupanja Europskoj uniji i komercijalizacije medijskih i komunikacijskih tržišta?

U pokušajima odgovaranja, ili barem integriranoga problematiziranja, na ta i druga pitanja polazimo od stajališta da je komunikacija osnova svih društvenih i kulturnih procesa, a da mediji na razne načine mijenjaju komunikacijske oblike (Krotz, 2007., 2009.). Mediji u isti mah djeluju na četiri razine: kao tehnologije, društvene institucije, organizacijski aparati te kao distributeri sadržaja i otvaranja prostora za razna iskustva primatelja tih sadržaja (Krotz, 2009.). Pritom se usredotočujemo na društvenu i institucionalnu razinu, jer nam ona omogućuje sagledavanje procesa na višim razinama općenitosti i 
DRUŠ. ISTRAŽ. ZAGREB GOD. 21 (2012),

BR. 4 (118),

STR. $821-842$

BILIĆ, P.:

HRVATSKI MEDIJSKI... jer bi sagledavanje pojedinačnih medija i procesa zahtijevalo publikaciju znatno većeg opsega, ali i drugačijega konceptualnog fokusa. Dva su ključna teorijska okvira važna za ovaj rad: prvo, teorija refleksivne modernizacije, kao jedna od najutjecajnijih društvenih teorija u sociologiji i društvenim znanostima već više od dva desetljeća; drugo, teorija medijatizacije kao rezultat suvremenih stremljenja $\mathrm{k}$ teorijskoj integraciji i stvaranju društvene i kulturne teorije medija i komunikacije, prije svega na njemačkom i skandinavskom govornom području. Osnovna je teza rada da hrvatski medijski sustav prolazi kroz važne promjene, koje se teorijski mogu karakterizirati kao paralelno odvijanje procesa refleksivne modernizacije i medijatizacije. Ti se pak procesi događaju neovisno o funkcionalnim promjenama u zakonodavnome sustavu, fragmentiranim medijskim politikama ili vrijednosnim orijentacijama stanovništva i medijskih publika.

Prvo se poglavlje sastoji od dva dijela. U prvome iznosimo osnovne postavke teorija refleksivne modernizacije, kojima su najviše pridonijeli Ulrich Beck, Anthony Giddens i Scott Lash. Drugi dio prvoga poglavlja posvećen je teorijama medijatizacije koje su, u raznim varijantama i kroz stavljanje naglaska na razne društvene i kulturne aspekte, razvili Friedrich Krotz, Stig Hjarvard i Winfried Schulz. Drugo se poglavlje bavi specifičnostima hrvatskoga medijskog sustava, koje objašnjavamo koristeći se pretpostavkama teorija refleksivne modernizacije i medijatizacije. Neke od ključnih razvojnih tendencija koje će se obrađivati jesu restrukturiranje javnoga servisa, liberalizacija i privatizacija medijskoga sustava, komercijalizacija medijskoga sadržaja i prodor globalnih kulturnih industrija, utjecaji EU-a te sve veća uloga interneta i novih medijskih platformi. U zaključku donosimo vrednovanje cjelokupnoga procesa i stanja u medijskom sustavu uz pomoć ovih dviju dominantnih razvojnih teorija.

\section{DVIJE KOMPLEMENTARNE TEORIJE DRUŠTVENE I KULTURNE METAPROMJENE}

Refleksivna modernizacija i medijatizacija polaze od stajališta da se mogu definirati određene karakteristike i procesi koji čine specifikum društava tzv. druge, kasne ili refleksivne moderne i koji ih odvajaju od društava i temeljnih procesa tzv. prve moderne. U okviru refleksivne modernizacije riječ je o društvenim (npr. mijenjanje rodnih uloga i društvene stratifikacije), političkim (npr. izvaninstitucionalni pokreti, potpolitika, nadnacionalni i transnacionalni procesi) i ekonomskim (npr. radnim, proizvodnim, potrošačkim) promjenama koje mijenjaju temelje modernih društava. Modernizacija se u ovome smislu ne odnosi na proces mijenjanja ili unapređenja pro- 
DRUŠ. ISTRAŽ. ZAGREB GOD. 21 (2012)

BR. $4(118)$

STR. $821-842$

BILIĆ, P.:

HRVATSKI MEDIJSKI... cesa upravljanja ili funkcioniranja nekoga društvenog podsustava (poput ekonomije, politike, kulture, znanosti i sl.), ${ }^{2}$ nego na društveni proces promjene koji nije uvijek racionalno vođen niti se može potpuno kontrolirati. Međutim, tek je neznatan dio teorija refleksivne modernizacije posvećen komunikaciji i medijima. Teorija medijatizacije, s druge strane, polazi od pretpostavke da upravo brojnost medija u društvima refleksivne i kasne moderne čini jednu od njezinih glavnih odrednica te da promjene komunikacijskih oblika i komunikacijskih mogućnosti uvelike mijenjaju sama društva i kulture. Stoga su te dvije teorije bliske i u mnogim aspektima komplementarne.

\section{Refleksivna modernizacija}

Naziv refleksivna modernizacija prvi je upotrijebio Ulrich Beck kako bi opisao procese koji dovode do nastanka druge ili refleksivne moderne i prijelaza iz industrijskoga društva u tzv. društvo rizika. Beck ih (1992.) uspoređuje s procesima koji su rastvarali temelje feudalnoga društva u 19. stoljeću i doveli do nastanka industrijskoga društva. Ovu drugu modernizaciju on naziva refleksivnom, jer se modernizirano društvo suočava samo sa sobom, a prijelaz iz industrijskoga društva u rizično odvija se nenamjeravano, skriveno i u skladu s obrascem latentnih sporednih učinaka. Društveni se sustavi druge modernosti oblikuju uz pomoć specifične funkcionalne diferencijacije. U njoj su granice između podsustava višeznačne, ambivalentne i dopuštaju mogućnost vlastita nadilaženja. Odluke se pritom ne donose $\mathrm{u}$ zatvorenom krugu stručnjaka, nego s pomoću složenih procesa pregovaranja (Beck, 1994.).

Refleksivnu modernizaciju na sličan način teoretizira Anthony Giddens. Temeljne institucionalne dimenzije modernosti jesu kapitalizam, odnosno akumulacija kapitala u kontekstu kompetitivnoga tržišta rada i proizvoda; industrijalizam, odnosno transformacija prirode; vojna moć, odnosno kontrola sredstava nasilja; i nadzor, odnosno kontrola nad informacijama i društveno nadgledanje (Giddens, 1990.). Ove institucionalne dimenzije mijenjaju se zbog refleksivnosti modernoga života. To za Giddensa znači da se društvene prakse neprestano ispituju u svjetlu novih informacija o samim tim djelatnostima, tako da se njihove karakteristike sadržajno mijenjaju. Posljedice modernosti za njega znače globaliziranje njezinih institucionalnih dimenzija, a sama globalizacija "intenzifikaciju društvenih odnosa na svjetskom planu".

Beck i njegovi suradnici Bonnss i Lau (2003.) tretiraju refleksivnu modernizaciju kao društvenu metapromjenu. Jedan od glavnih mehanizama društvene promjene jest bujanje latentnih sporednih učinaka. Oni su rezultat preokreta uzrokova- 
DRUŠ. ISTRAŽ. ZAGREB GOD. 21 (2012),

BR. 4 (118),

STR. $821-842$

BILIĆ, P.:

HRVATSKI MEDIJSKI...

\section{Medijatizacija}

nih javnim diskursom i političkim argumentima kolektivnih aktera, koji uključuju potrošače, masovne medije i nove društvene pokrete. Zbog toga je metapromjena rezultat javne refleksije o tehničkim obećanjima sigurnosti društva prve moderne. Tijekom toga procesa mijenjaju se društveni prioriteti i očekivanja, dok rizici i iščekivanja katastrofe dominiraju u javnim debatama prije donošenja odluka (Beck i sur., 2003.). Autori nadalje iznose opće analitičke kriterije koji trebaju pomoći pri operacionalizaciji i testiranju teorije refleksivne modernizacije. Oni polaze od pretpostavke da se u refleksivnoj modernizaciji granice između društvenih sfera (poput ekonomije, politike ili kulture) umnožavaju.

Za razliku od ovih autora, Scott Lash (1994.) smatra da je refleksivna modernizacija rezultat nestajanja određenih društvenih struktura i njihove zamjene informacijskim i komunikacijskim strukturama. U industrijskom su kapitalizmu "životne šanse", odnosno mogućnosti društvenoga napredovanja, bile određene klasnim nejednakostima, tj. položajem u sredstvima proizvodnje i pristupom tim sredstvima. U refleksivnoj modernizaciji one ovise o pristupu i položaju u informacijskim i komunikacijskim strukturama. Ove se strukture sastoje od umreženih kanala informacijskih tokova i prostora u kojima se prisvajaju i obrađuju informacije (Lash, 1994.). Dalekosežne društvene i duboke strukturne promjene prema Lashovu su mišljenju pod snažnim utjecajem razvoja novih informacijskih i komunikacijskih tehnologija te također s njima povezanim promjenama oblika rada i proizvodnje, kao i stvaranja novih oblika društvenih nejednakosti. Međutim, njegov je fokus na društvenoj stratifikaciji, a ne na komunikacijskim procesima ili tehnološkim i institucionalnim promjenama medijskih institucija koje su u središtu teorija medijatizacije.

Sama brojnost izvora informacija ili tehnološki napredak u smislu otvaranja novih komunikacijskih mogućnosti i potencijala nisu dovoljni za društvenu i kulturnu promjenu. Iza tih promjena uvijek stoje ljudi i društvene skupine s raznim vrijednostima, motivima, ciljevima i interesima, kojima nastoje prilagoditi i promijeniti društvenu i kulturnu stvarnost. Međutim, danas sve više medija posreduje $u$ procesima promjene, $i$ to do te mjere da Sonia Livingstone (2009.) tvrdi kako je danas sve posredovano, jer se sve utjecajne društvene institucije transformiraju i obnavljaju prilikom suvremenih procesa medijskoga posredovanja ili medijacije. Društvene promjene suvremenih društava visoke ili kasne moderne obilježene su medijima i medijskom komunikacijom (Lundby, 2009.).

Prema mišljenju Friedricha Krotza (2007.), mediji su neraskidivo povezani s komunikacijom i služe promjeni oblika ko- 
DRUŠ. ISTRAŽ. ZAGREB GOD. 21 (2012) BR. 4 (118)

STR. $821-842$

BILIĆ, P.: HRVATSKI MEDIJSKI.. munikacije i komunikacijskih uvjeta. Medijatizacija je pritom dugotrajan metaproces promjene, koji, promjenom medija i oblika komunikacije, traje od izuma pisma do danas, proizvodeći na razne načine složene interakcije i promjene $u$ ljudskoj svakodnevici, identitetu, društvenim odnosima, kulturi i društvu u cjelini. Ovaj dugotrajni društveni metaproces može se analizirati na raznim razinama društvene stvarnosti, dok istodobno ovisi o društvenim i povijesnim specifičnostima unutar kojih se odvija. Krotz (2009.) smatra da je medijatizacija proces koji nije samo dio drugih metaprocesa, poput globalizacije i individualizacije, nego je s njima usporediv i komplementaran. On na taj način naglašava procesualni značaj promjene medija i komunikacija, čime se želi razgraničiti od statičnih interpretacija medijskoga društva ili društva zasićenoga medijskim interpretacijama.

Mediji kao institucije u središtu su teorije medijatizacije koju razvija Stig Hjarvard. On smatra da se u suvremenom, visokorazvijenom $\mathrm{i}$ industrijaliziranom društvu mediji ne mogu promatrati odvojeno od drugih kulturnih i društvenih institucija. Medijatizacija društva za njega podrazumijeva procese $\mathrm{u}$ kojima društvo u zamjetnoj mjeri postaje podređeno $\mathrm{i}$ ovisno o medijima i njihovoj specifičnoj logici. To znači da su mediji integrirani $u$ djelovanje drugih društvenih institucija te da se društvena interakcija unutar institucija, između institucija i u društvu u cjelini odvija uz pomoć medija. Mediji interveniraju i utječu na aktivnosti drugih institucija kao što su obitelj, politika, religija itd., a istodobno otvaraju zajednički forum za društvo u cjelini (Hjarvard, 2008.). Medijatizaciju vidi kao modernizaciju i uspoređuje ju s urbanizacijom i individualizacijom, jer mediji utječu na izdizanje ili iskorjenjivanje društvenih odnosa iz pojedinoga društvenog i kulturnog konteksta i njihovo ponovno ukorjenjivanje u nove kontekste.

Winfried Schulz (2004.) također smatra da se medijatizacija odnosi na promjene povezane s komunikacijskim medijima i njihovim razvojem. On utvrđuje četiri glavne promjene u kojima mediji imaju glavnu ulogu: protezanje, zamjena, prožimanje i prisvajanje. Medijske tehnologije omogućuju protezanje ljudske komunikacije mimo njezinih prirodnih ograničenja. Mediji djelomično ili potpuno zamjenjuju pojedine društvene aktivnosti i institucije te istodobno mijenjaju njihov karakter, no omogućuju i miješanje raznih društvenih aktivnosti i institucija. Raznorazni akteri i organizacije s područja ekonomije, politike, sporta, zabave i drugih društvenih područja prisvajaju medije na razne načine. Proces medijatizacije u Schulzovoj interpretaciji ne poznaje razliku između masovnih ili "tradicionalnih" i novih medija, jer se četiri glavna procesa promjene mogu primijeniti na bilo koju vrstu medija i 
DRUŠ. ISTRAŽ. ZAGREB GOD. 21 (2012),

BR. 4 (118),

STR. $821-842$

BILIĆ, P.:

HRVATSKI MEDIJSKI... komunikacijskog oblika. To podrazumijeva kontinuitet u razvoju medijskih sustava, što čini ovaj pristup prilagodljivim raznim stupnjevima medijskog razvoja (Schulz, 2004.).

U kojem kontekstu možemo govoriti o Hrvatskoj iz perspektive teorija refleksivne modernizacije i medijatizacije? Raspadom Jugoslavije Hrvatska je otpočela tranzicijski proces ili proces transformacije cjelokupnoga društvenog sustava i njegovih podsistema (Švob-Đokić, 2000.). Taj je proces bio otežan i usporen ratnim stanjem iz prve polovice devedesetih godina, dok je u zadnjoj polovini prvoga desetljeća 21. stoljeća obilježen pristupanjem Europskoj uniji. S obzirom na takve razvojne specifičnosti, treba se zapitati je li refleksivna modernizacija odlika društvenog razvoja zapadnih, postindustrijaliziranih društava ili se odnosi na stadij u kojem upravljačke politike ne mogu, ili nisu kadre, potpuno predvidjeti društvene rizike iz čega proizlaze nenamjerne društvene posljedice? I $u$ slučaju potvrdna odgovora, može li se primijeniti na hrvatsku situaciju? Josip Županov $(2002 ., 10)$ nudi dio odgovora na to pitanje: "[a]ko se istočni socijalizam shvati kao povijesna aberacija $u$ procesu modernizacije, a tranzicija kao vraćanje sa stranputice na glavnu trasu povijesnog razvoja, onda ju je ispravnije shvatiti kao fazu u procesu društvene evolucije nego li kao preobraćenje na 'pravu vjeru' i ispravljanje pogrešaka. Naime, proces evolucije je jedna komplicirana aleatorna igra u kojoj ima mnogo slijepih ulica i neuspjelih oblika. Opstaju samo oni koji su se prilagodili. Nema nikakve garancije da će sve zemlje u tranziciji izbiti na povijesnu magistralu razvoja i opstati kao moderna društva". Gledano iz takve razvojne perspektive i uspoređujući je s refleksivnom modernizacijom, teško možemo govoriti o čistim ili idealnim oblicima druge moderne s kojima bi se društveni razvoj mogao usporediti. Paul Blokker (2005.) također smatra da sam proces modernizacije ne vodi konvergenciji s nekakvim idealtipskim zapadnim sustavom, nego zbog brojnosti agenata, programa i institucijskih konfiguracija dovodi do stvaranja raznih društvenih poredaka. U smislu funkcionalne diferencijacije sustava, teško se možemo složiti da je hrvatski društveni, politički, ekonomski, medijski i kulturni sustav potpuno prilagođen refleksivnoj modernizaciji. No usprkos tomu, izložen je jednakim globalnim rizicima i procesima globalizacije kao i druga kasnomoderna društva, pri čemu se suočava sa sličnim problemima.

Pojedini autori pokušavaju odgovoriti na hrvatske modernizacijske procese orijentacijom na vrijednosne promjene, pa na tome tragu hrvatsko društvo nazivaju mješovitim dru- 
DRUŠ. ISTRAŽ. ZAGREB GOD. 21 (2012)

BR. 4 (118)

STR. $821-842$

BILIĆ, P.:

HRVATSKI MEDIJSKI... štvom (Tomić-Koludrović i Petrić, 2007.). Time se želi naglasiti da, osim izloženosti procesima druge modernizacije, u Hrvatskoj ipak prevladavaju vrijednosti karakteristične za prvu modernizaciju, poput kolektivističkih vrijednosti iz socijalističke prošlosti ili vrijednosti povezanih s izgradnjom nacionalne države. Hrvatska se sigurno prema mnogim kriterijima ne može svrstati među razvijena postindustrijska društva. Međutim, orijentacija na vrijednosne promjene samo je djelomično primjenjiva na analizu promjene medijskoga sustava. Konceptualno, ona ne može odgovoriti na pitanje kako su tehnološke, institucionalne, organizacijske i sadržajne promjene medijske proizvodnje utjecale na vrijednosne promjene stanovništva, odnosno medijskih publika. Jedini logičan zaključak izveden iz takve pozicije bio bi analiza učinaka medijskoga sadržaja na vrijednosni sustav. Međutim, teorija direktnih medijskih učinaka jest pozicija koja danas sve više ustupa mjesto drugačijim analizama. Orijentacija na vrijednosne promjene ne može obuhvatiti cjelokupnost društvenih procesa koji su povezani s medijskim i komunikacijskim promjenama a da ne završi u konceptima kao što su dominantne vrijednosti ili prevladavajuće vrijednosti jednoga društva. Ove vrijednosti ne mogu do kraja objasniti ni specifične medijske dijete ${ }^{3}$ koje današnji individualizirani medijski potrošači konzumiraju. $S$ druge strane, John B. Thompson sistemske promjene društva traži u kulturnim transformacijama koje su povezane s razvojem medija i komunikacijskih struktura. On smatra da su se društveni teoretičari mahom pogrešno usmjerili na proučavanje promjena vrijednosti, uvjerenja, stavova i orijentacija tražeći dokaze o sustavnim kulturnim promjenama. Stoga predlaže promjenu središta analize na simboličke forme i načine njihove proizvodnje i cirkulacije u društvenom svijetu, odnosno na proces "medijacije kulture" (eng. mediation of culture) (Thompson, 1995.).

\section{KONTEKST PROMJENA HRVATSKOGA MEDIJSKOG SUSTAVA}

U protekla dva desetljeća medijski je sustav prolazio kroz znatne strukturne promjene, koje su povezane u prvom redu s uspostavljanjem određenih demokratskih vrijednosti te liberalizacijom i privatizacijom medijskih tržišta. Uloga države u tom procesu bila je ključna, a broj aktera koji sudjeluju u procesu donošenja specifičnih medijskih regulativa stalno se povećavao zajedno s postupnim uspostavljanjem demokratskoga standarda provođenja javnih rasprava. Taj proces, naravno, nije bio jednostavan, nego se s različitom dinamikom odvijao kroz razna razdoblja, ${ }^{4}$ ovisno o društveno-političkim promjenama, promjenama na medijskom tržištu i tehnološkom razvoju. Prvo je razdoblje trajalo od 1990. do 1999. godine. U 
DRUŠ. ISTRAŽ. ZAGREB GOD. 21 (2012),

BR. 4 (118),

STR. $821-842$

BILIĆ, P.:

HRVATSKI MEDIJSKI... njemu su se odvijali procesi izgradnje države i bio je obilježen nacionalnim televizijskim monopolom. Pitanja privatnosti, ugleda i zaštite dostojanstva imala su primat nad slobodnim protokom informacija i pravom javnosti na informiranje (Peruško-Čulek, 1999.). U tom je razdoblju medijska politika bila oblikovana bez javnoga konsenzusa ili konzultacije stručnjaka (Zgrabljić Rotar, 2003.). Liberalizacija medijskoga tržišta provedena je samo u tisku, a utjecaj novih tehnologija bio je rudimentaran. Drugo razdoblje traje od 2000. do 2003. godine. Osim promjene parlamentarne strukture, liberalizirano je telekomunikacijsko i televizijsko tržište i uvedene su osjetne promjene upravljačke strukture državne, odnosno javne televizije. Utjecaj interneta i novih medija postupno je rastao. Treće razdoblje traje od 2004. do danas. Obilježeno je procesom usklađivanja medijskoga zakonodavstva u procesu pristupanja Europskoj uniji te porastom značenja interneta, mrežnih stranica i širega prodora potrošačkih i popularnokulturnih globalnih proizvoda. Medijsko je tržište u istom razdoblju doživjelo velik uspon povezan sa samom brojnosti medija, ali je dovelo i do trendova medijske koncentracije koji utječu na opću razinu pluralizma medijskoga sustava (Peruško, 2003.). Detaljno govoreći, hrvatski se medijski sustav danas sastoji od približno 870 tiskanih medija, ${ }^{5} 30$ televizijskih kanala, od kojih je devet s nacionalnom koncesijom, ${ }^{6} 168$ radijskih postaja, od kojih je $5 \mathrm{~s}$ nacionalnom koncesijom, 7 i 66 pružatelja internetskih usluga. 8 Postoji i 20 kabelskih operatera za distribuciju televizijskih kanala, dva satelitska, četiri internetska, jedan DTT multiplex operater i jedan mobilni TV operater. ${ }^{9} \mathrm{Vi}-$ še od samoga broja medija, o prirodi medijskoga sustava i ulozi koju pojedini mediji u njemu imaju govore dvije ključne odrednice: prva je vlasništvo nad medijima, koje je u rukama tek nekoliko medijskih kompanija ili države, a druga su dosezi u publikama.

\section{Javni medijski servis kao produžena institucija prve moderne}

U modernim, prije svega europskim, medijskim sustavima 20. stoljeća o javnoj sferi10 možemo govoriti u kontekstu strukturalno određenih servisa javnoga masovnomedijskog emitiranja. Sustav javnog emitiranja, odnosno javne sfere, zauzima središnje mjesto u medijskom sustavu jer djeluje kao sustav posredovanja, preuzimanja i obradbe određenih tema i mišljenja, odnosno djeluje kao sustav posredovanja između građana i političkoga sustava (Gerhards i Neidhardt, 1990.). Takva pozicija javnih servisa u medijskom je sustavu bila rezultat manjih mogućnosti frekvencijskoga spektra, koje su danas povećane zbog tehnoloških kapaciteta satelitske, kabelske i digitalne televizije te uspona interneta i izvora informacija koje 
DRUŠ. ISTRAŽ. ZAGREB GOD. 21 (2012) BR. 4 (118)

STR. $821-842$

BILIĆ, P.: HRVATSKI MEDIJSKI.. primamo preko njega. Monopolna pozicija javnoga servisa na taj je način sve ugroženija, jer u kasnomodernom društvu nema jasno ocrtanih granica između pojedinih medija zbog toga što su brojnost, dostupnost i načini njihove upotrebe umnoženi. Na taj je način stabilnost masovnomedijske javne sfere u smislu dosega u publikama i postavljanja agende u suvremenim društvenim i medijskim sustavima onemogućena raznim mogućnostima proizvodnje i potrošnje sadržaja, odnosno alternativnim izvorima komunikacije i informiranja.

Proces restrukturiranja ili uspostavljanja hrvatske nacionalne i javne radiotelevizije u 1990-ima bio je usmjeren na širi proces odvajanja države od društva. U tom procesu mediji "(... ) postaju glavni akteri uspostavljanja nove javne sfere, te izrazito utječu na uspješnost ukupne društvene tranzicije" (Peruško-Culek, 1999., 6). U 1990-ima Hrvatska radiotelevizija bila je jedina televizija s nacionalnim dosegom. Politički je utjecaj bio vidljiv u radu Programskoga vijeća, u kojem je 15 članova od ukupno 19 bilo među parlamentarnim predstavnicima vladajuće stranke (Zgrabljić Rotar, 2003.). Zadržani status monopolnoga nacionalnog servisa održao je HRT kao instituciju prve moderne u povijesnim uvjetima ubrzane globalizacije, uspona globalnih medijskih kompanija te liberalizacije nacionalnih medijskih tržišta. Javni je servis imao jasnu društvenu funkciju posredovanja između politike i građana te izgradnje homogenoga nacionalnog i kulturnog identiteta. Dakle, funkcionalna je diferencijacija ${ }^{11}$ medijskoga sustava u Hrvatskoj slijedila logiku političkog i stranačkog interesa, jer se društveni status javnoga servisa nije znatno promijenio $u$ usporedbi sa socijalističkim razdobljem. Prve značajne promjene uslijedile su 2001. godine, kada je nakon niza javnih rasprava donesen novi Zakon o Hrvatskoj radioteleviziji. HRT je tada organiziran kao "javna institucija" koja "promiče interese javnosti" i "odgovara na javne interese". U Programskom vijeću dominantnu su ulogu preuzeli članovi civilnoga društva. Prva se restrukturacija, dakle, odnosila na promjenu institucionalnoga položaja iz državne televizije u javnu televiziju, dok je druga rezultat funkcionalne krize tada uspostavljenoga servisa te vanjskih utjecaja i pritisaka. Potkraj prvoga desetljeća 21. stoljeća HRT se našao u višestrukoj krizi: financijskoj, zbog neodgovorna trošenja sredstava, upravljačkoj, koja se odnosi na postavljanje novoga glavnog ravnatelja, kadrovskoj, zbog prevelikoga broja zaposlenika, i demokratskoj, zbog raznih oblika cenzure (Popović i sur., 2010.). Nakon dugotrajnih rasprava potkraj 2010. godine usvojen je novi zakon sa zamjetnim promjenama upravljačke strukture i njezine kontrole te ukupnoga financijskog poslovanja kuće. To je uvelike promijenilo ukupnu sliku televizijskoga tržišta, jer je proces 
DRUŠ. ISTRAŽ. ZAGREB GOD. 21 (2012),

BR. 4 (118),

STR. $821-842$

BILIĆ, P.:

HRVATSKI MEDIJSKI.. tekao usporedno s uspostavljanjem digitalne televizije i novih kanala te s procesima pregovaranja s Europskom unijom, koji su zahtijevali reguliranje državne potpore i veću liberalizaciju televizijskoga tržišta. ${ }^{2}$ Javna se politika u tom kontekstu nije vodila holističkim pristupom, jer je uvođenje nove upravljačke strukture stavilo pred javnu televiziju izazov adaptacije na novi zakon, dok je proces digitalizacije televizijskoga tržišta već obavljen..$^{13}$ Time se kriza HRT-a dodatno produbila.

\section{Liberalizacija i privatizacija tržišta - pomicanje granice javnoga i privatnoga}

U medijskom je sustavu tranzicija podrazumijevala liberalizaciju tržišta i privatizaciju dotadašnjih medija. Najprije se privatiziralo tržište tiska u 1990-ima. U to je vrijeme nacionalnim televizijskim tržištem dominirao HRT s monopolom na nacionalno emitiranje, a prve komercijalne televizije započinju s emitiranjem 2000. godine (Nova TV), odnosno 2004. godine (RTL televizija). U 1990-ima dominantna je tema bilo odvajanje politike i države od medija, a u novom tisućljeću dolazi do "promjene paradigme moći" (Peruško, 2003.), jer sve veći utjecaj na medijski sustav počinju dobivati privatni i ekonomski interesi. Zrinjka Peruško (2003., 41) tako ističe: "[p]itanje smjenjivanja države s mjesta kontrolora medija, koje nas je najviše zabavljalo $\mathrm{u}$ prvim analizama razvoja medijskih sustava $\mathrm{u}$ tranzicijskom razdoblju, odvuklo nam je pozornost s činjenice da je u svim medijskim sustavima važno osigurati da kontrola medija nije usmjerena iz jednog središta. Kontrola države isto je tako loša kao kontrola velike korporacije".

Današnje je stanje medijskoga tržišta (Popović i sur., 2010.) takvo da su dnevne novine s najvećim dosezima u publikama u vlasništvu dviju stranih kompanija. Austrijska kompanija Styria Media International AG posjeduje novine 24 sata $(31 \%$ publike 2009.) i Večernji list (13,4\%). Njemačka Westdeutsche Allgemeine Zeitung Gruppe, najveći dioničar Europapress Holdinga, posjeduje Jutarnji list $(13,6 \%)$ i Slobodnu Dalmaciju $(6,8 \%)$. Nova TV u stopostotnom je vlasništvu kompanije Central European Media Enterprises iz Nizozemske, a RTL u vlasništvu RTL grupe. Udio u televizijskim publikama za HRT (HRT 1 i HRT 2) iznosio je 2009. godine $42,8 \%$, dok je RTL imao $22,2 \%$, a Nova TV $20,6 \%$. Telekomunikacijska je infrastruktura prvi put privatizirana 1999 . godine, kada je prodano $35 \%$ dionica Hrvatskih telekomunikacija kompaniji Deutsche Telekom (DT). Godine 2001. DT je kupio preostalih 16\% i tako stekao većinsko vlasništvo. Dominantan pružatelj internetskih usluga jest T-com (kao dio DT-a) sa $72 \%$ internetskih korisnika. Aktualni primjer tehnoloških promjena, odnosno uspostave digitalnoga zemaljskog emitiranja, rezultirao je jača- 
DRUŠ. ISTRAŽ. ZAGREB GOD. 21 (2012)

BR. $4(118)$

STR. $821-842$

BILIĆ, P.:

HRVATSKI MEDIJSKI... njem pozicije komercijalnih televizija, dodatno pomičući granicu između javne i komercijalnih televizija u korist komercijalnih. Naime, istodobno s procesom digitalizacije, dvije nacionalne televizijske kuće dobile su nove specijalizirane programe (RTL RTL2, a Nova TV Domu TV) dok HRT nije uspostavio specijalizirane kanale vjerojatno zbog institucionalne krize jer je zakonski imao tu mogućnost.

Iako je otvaranje tržišta u početku dočekano s odobravanjem i s visokim očekivanjima zbog postizanja raznolikosti (Peruško, 2003.), otvorilo je prostor i nizu neočekivanih i latentnih društvenih posljedica. Među njima je proces medijske koncentracije, koji je usto i rezultat maloga tržišta, prodiranje raznih oblika zabavnog, potrošačkog i popularno-kulturnog sadržaja te raznorazni pritisci na novinarsku profesiju. Ovi su pritisci rezultat činjenice da komercijalne medijske kompanije svoj poslovni model temelje na dosezima u publikama koje prodaju zainteresiranim oglašivačima, a ne u kvaliteti proizvoda i visokim standardima novinarske profesije. Kroz smanjenje utjecaja državnih, odnosno javnih, medija i povećanje utjecaja, komercijalnih kompanija medijsko je tržište u znatnom dijelu otvoreno globalnim utjecajima, ostavljajući nacionalni medijski prostor bez velikih mogućnosti upravljanja, osim osiguranja uvjeta tržišnoga natjecanja ili popravljanja statusa novinara.

\section{Promjena paradigme medijskoga sadržaja}

Otvaranje medijskoga tržišta dovelo je do promjena u proizvodnji medijskoga sadržaja, a time i do promjena u kulturi i društvu. Povećana dostupnost medijskoga sadržaja zabavnoga karaktera dovela je do povećanoga kolanja proizvoda popularne kulture te raznih medijskih formata, poput kvizova, reality show emisija i sl., bilo u izvornom ili lokaliziranom obli$\mathrm{ku}$, iz dominantne američke kulturne industrije. Gledajući s toga stajališta, hrvatsko je društvo potpuno globalizirano, jer je potrošačko društvo stvarno postojeće svjetsko društvo (Beck, 2004.), a u tom globalnom društvu sve se više rabe, odnosno troše, znakovi i simboli (Lash i Urry, 1994.). Unatoč činjenici da je Televizija Zagreb (prethodnica HRT-a) bila dio EBU Eurovision razmjene programa, čime je imala pristup vijestima, dokumentarnomu i zabavnomu programu zapadnih zemalja (Peruško i Popović, 2008.), razdoblje nakon 2000. može se nazvati razdobljem uspostave prave dominacije zabavnoga i komercijalnoga medijskog sadržaja.

Ukupna proizvodnja sadržaja na HRT-u u usporedbi s komercijalnim televizijama pokazuje da HRT ima veću raznolikost žanrova i prikazuje više "društveno korisnog" sadržaja, dok komercijalne televizije proizvode više zabavnoga i fiktiv- 
DRUŠ. ISTRAŽ. ZAGREB GOD. 21 (2012),

BR. 4 (118),

STR. $821-842$

BILIĆ, P..:

HRVATSKI MEDIJSKI.. noga sadržaja (Peruško, 2009.). No usprkos tome, prema podacima o televizijskim publikama, od 2005. do 2009. godine dnevni udio u publikama za HRT (HRT 1 i HRT 2) pao je sa $54 \%$ na $43,8 \%$ dok su komercijalne televizije (Nova TV i RTL) porasle sa $38,3 \%$ na $42,8 \%$. U istom je razdoblju u udarnome terminu udio javne televizije pao sa $57,8 \%$ na $43,4 \%$ dok se udio komercijalnih televizija povećao sa $36,4 \%$ na $46,6 \% .{ }^{14}$ Prema nekim istraživanjima, od 2005. do 2008. godine središnja informativna emisija, Dneonik HRT-a, pokazuje trend pomaka od informativnoga programa prema informativno-zabavnomu programu (infotainmentu) u bitki za naklonost medijskih publika s komercijalnim televizijama (Perišin, 2008.).

Pad gledanosti, odnosno povjerenja u program javne televizije, govori da gledatelji teže prepoznaju svoje interese na javnoj televiziji. U medijskom sustavu, u kojem brojnost izvora informacija stalno raste, sinkroniziranost između emitiranja javne televizije i očekivanja, interesa te preferencija medijske publike teško se može očekivati. Takvo stanje u medijskom sustavu ima dvije posljedice: fragmentarnost javne sfere kao nusproizvod manje mogućnosti kontrolirane debate monopolnog emitiranja, odnosno kontrolirane proizvodnje sadržaja, i veću mogućnost izbora informacija medijskih publika, ne samo na televiziji nego i preko interneta i drugih novih medijskih platformi.

\section{Centrifugalni i centripetalni utjecaji Europske unije}

Sloboda izražavanja, neovisnost i pluralizam medija temeljna su demokratska načela. Njihovo je usvajanje u hrvatskom medijskom sustavu teklo sporo, osobito 1990-ih godina. Pritisci na HRT i neovisne medije te netolerantnost prema novinarima i medijima bili su među važnijim razlozima usporavanja ulaska Hrvatske u europske integracije (Peruško, 2005.). Hrvatska i Europska unija potpisale su Sporazum o stabilizaciji i pridruživanju 2001. godine, koji je stupio na snagu četiri godine potom. Godine 2004. Hrvatska je postala zemlja kandidatkinja za ulazak u EU, a pregovori su formalno započeli 2005. godine. Pregovori u poglavlju 10 (Informatičko društvo i mediji) privremeno su zatvoreni još 2009., dok su ukupni pregovori završeni u lipnju 2011. godine. Uz pomoć direktiva kao specifično postavljenih ciljeva za usklađivanje zakonodavstva u raznim zemljama, Europska unija izravno utječe na konfiguracije europskih medijskih sustava. Hrvatsko je zakonodavstvo ${ }^{15}$ prenijelo dvije direktive koje su se odnosile na elektroničke medije, odnosno audiovizualne medije: Direktivu o televiziji bez granica te Direktivu o audiovizualnim uslugama. Direktiva o televiziji bez granica ${ }^{16}$ rezultat je povijesnih okolnosti povezanih s razvojem satelitske televizije i usponom globalnih komercijalnih medijskih kuća, prije svega iz 
DRUŠ. ISTRAŽ. ZAGREB GOD. 21 (2012)

BR. $4(118)$

STR. $821-842$

BILIĆ, P.:

HRVATSKI MEDIJSKI..
SAD-a. Godine 1989. Europska komisija (EK) usvojila ju je uz pomoć kvota za emitiranje na komercijalnim i javnim televizijama, a s ciljem zaštite maloljetnika i potrošača te zaštite europskih audiovizualnih djela. Godine 2007. Komisija proširuje odredbe i na druge načine pružanja audiovizualnih usluga, poput videa na zahtjev.

Osim prenošenja direktiva u lokalno zakonodavstvo, utjecaj EU-a vidi se i u pritiscima na liberalizaciju tržišta elektroničkih komunikacija i audiovizualnoga tržišta, na jačanje državnih regulatora i uređivanje državnih potpora javnoj televiziji. Naime, u svim izvještajima o napretku pregovora od 2005. godine ${ }^{17}$ EK ističe potrebu učinkovite liberalizacije tržišta elektroničkih komunikacija. Izvještaji za 2009. i 2010. godinu govore o nekompetitivnim državnim potporama nacionalnoj audiovizualnoj produkciji te potrebi stvaranja kompetitivnijega audiovizualnog tržišta. U tom je kontekstu i zadnja restrukturacija HRT-a bila pod utjecajem EU-a i pristupnih pregovora. Nemogućnost vladanja prihodima od pretplate za komercijalne djelatnosti te smanjenje vremena oglašavanja u udarnome terminu neke su od tih posljedica.

Usprkos zatvaranju poglavlja 10 i završetku pregovora, medijski je sustav obilježen nizom nedorečenosti i problematičnosti koje su izvan utjecaja EU-a i ostaju u nadleštvu lokalnoga, odnosno nacionalnog, političkog i pravnog sustava. Prema analizi Freedom Housea za 2010. godinu, ${ }^{18}$ Hrvatska zauzima 85. mjesto od 196 zemalja i ima status djelomično slobodne zemlje na području sloboda tiska. Takav je status relativno stabilan u ovim izvještajima još od 2002. godine. ${ }^{19}$ EK u izvještaju o napretku pregovora s Hrvatskom za 2010. godinu navodi i slabo provođenje i primjenu zaštite ljudskih prava, trajanje sudskih postupaka, političkih i ekonomskih pritisaka na novinare te neovisnost lokalnih medija. Ako situaciju sagledamo cjelokupno, možemo reći da su utjecaji EU-a dvojaki. Centripetalni se utjecaji vide u liberalizaciji komunikacijskoga i medijskoga tržišta te uvođenju kvota za europska djela, dok se centrifugalni vide u pritiscima na usvajanje i provođenje općih demokratskih i ljudskih prava. Međutim, u tom kontekstu primjena ostaje glavni problem, osobito zato što se promjene medijskoga zakonodavstva donose iz potrebe za ubrzanim završavanjem procesa pregovora, dakle iz kratkoročnih političkih interesa, ostavljajući nedostatke specifične za lokalno hrvatsko medijsko tržište i medijski i komunikacijski sustav neriješenima.

\section{Sve veća uloga interneta i novih medija}

Internet je složen društveno-tehnički i komunikacijski medij. U tehničkom smislu, radi se o nizu globalno međusobno povezanih računala i servera te softverskih rješenja za njihovu 
DRUŠ. ISTRAŽ. ZAGREB GOD. 21 (2012), BR. 4 (118),

STR. $821-842$

BILIĆ, P.:

HRVATSKI MEDIJSKI... upotrebu. U društvenom smislu možemo govoriti o nizu nacionalnih i međunarodnih institucija, regulatora i organizacija koje utječu na njegovo djelovanje te o komercijalnim kompanijama usmjerenima prema pružanju osnovnih tehničkih usluga ili pružanju sadržaja. Internet je i medij koji omogućuje značajan rast alternativnih izvora informacija i mogućnosti proizvodnje sadržaja, kao što su blogovi ili Wikipedija. U komunikacijskom smislu, internet je "hibridni medij", jer omogućuje ostvarivanje raznih tipova komunikacije: međuljudsku komunikaciju, proizvodnju i recepciju različita sadržaja te komunikaciju s interaktivnim sustavima (Krotz, 2007.).

Broj korisnika interneta u Hrvatskoj porastao je s niskih $4,6 \%$ u 2000. godini na 50,0\% u 2010. godini, 20 a broj korisnika širokopojasnog interneta godine 2010 . iznosio je $25,5 \%$. U tom je razdoblju vrlo brzo rastao broj mrežnih stranica i novih medija. Glede informativnih mrežnih stranica u 2009. godini, najpopularnija je stranica dnevne tiskovine 24 sata $(14,4 \%)$, zatim net.hr $(12,4 \%)$ i index.hr $(11,8 \%)$ kao isključivo online mediji, T-portal (10,9\%), Njuškalo (9,1\%), jutarnji.hr (8\%) i večernji.hr $(7,9 \%) .{ }^{21}$ Ove stranice imaju sličnu medijsku i komunikacijsku logiku kao i masovni mediji radija i televizije, ali se zbog umrežavanja s drugim mrežnim stranicama i mogućnostima komentiranja članaka otvaraju horizontalnim oblicima komunikacije. Prema podacima za listopad 2011. godine,22 druga najpopularnija mrežna stranica u Hrvatskoj bio je društveni medij, odnosno web-stranica, za društvene mreže ${ }^{23}$ Facebook. Kao globalni predvodnik takve vrste komunikacije, on otvara prostor za interpersonalnu komunikaciju koja ujedno postaje društvena. Međutim, usprkos znatnim potencijalima u ostvarivanju oblika horizontalne komunikacije, ne treba zaboraviti da Facebook kao globalna kompanija ${ }^{24}$ ne funkcionira u vakuumu, nego da se iza mrežne stranice krije jedinstvena ekonomska i medijska logika. One su pronašle tržišnu nišu u kojoj se korisnici svjesno odriču privatnosti u zamjenu za koristi koje dobivaju od besplatne upotrebe servisa (Debatin i sur., 2009.). Robert W. Gehl (2010.) smatra da su Web 2.0 kompanije, poput Facebooka, rezultat "nelagodnoga primirja" između vlasnika tih mrežnih stranica koji žele zauzdati nepredvidive kreativne kapacitete korisnika mreže kako bi stvorili bogatstvo i moć te korisnika tih stranica koji žele biti dio tih medija, ali na načine koji su korisni za njih. Njihov ekonomski model bitno se ne razlikuje od modela tradicionalnih masovnih medija - oni prodaju udio i doseg u ciljanim publikama zainteresiranim oglašivačima; ali za razliku od masovnih medija, lišeni su odgovornosti za proizvodnju sadržaja, jer sadržaj proizvode sami korisnici. Međutim, u specifičnom povijesnom trenutku upravo je takva globalna komercijalna kompanija o- 
DRUŠ. ISTRAŽ. ZAGREB

BR. 4 (118),

STR. $821-842$

BILIĆ, P.:

HRVATSKI MEDIJSKI... GOD. 21 (2012)

tvorila prostor alternativnim komunikacijskim procesima za izražavanje različitih javnih interesa.

U Hrvatskoj se dogodilo nekoliko protuvladinih prosvjeda u kojima je medijsku pozornost dobila upotreba stranica za društvene mreže. Oni se mogu opisati kao reakcija na legitimacijsku krizu političkoga sustava oslabljenoga korupcijskim aferama, kao ogorčenje javnosti predugim procesom pregovaranja za ulazak u EU, kao i sve većom nezaposlenošću, osobito mladih, obrazovanih ljudi. Facebook kao komunikacijska platforma nije uzrok ovim događajima, ali ipak utječe na dinamiku i karakteristike tih prosvjeda, kao što su inovativan način kontrole medijske agende jer su se prosvjednici pojavljivali na raznim lokalitetima zbunjujući novinare u izvještavanju o tim događajima, umreženost i decentraliziranost te brzina organizacije i razmjena informacija.

Iz perspektive medijskoga sustava, ovaj i drugi slični slučajevi zorno pokazuju kako se u suvremenim medijskim i komunikacijskim sustavima mijenjaju granice između politike, javnih, privatnih i komercijalnih interesa te komunikacijskih oblika, odnosno institucionalizirane masovne komunikacije i "masovne samokomunikacije". ${ }^{25}$ Medijatizacija izvaninstitucionalnih društvenih procesa odvija se tako kroz razne medije, a javni se interesi sve više ističu kroz nove medije, usprkos njihovu komercijalnom karakteru, kao u slučaju Facebooka. Međutim, otvaranje digitalnoga prostora na internetu ne znači automatski slobodan prostor za razvijanje demokracije ili novih oblika javne sfere. Akteri koji posjeduju političku i financijsku moć imaju početnu prednost $\mathrm{u}$ osvajanju toga prostora. Upotreba potencijala alternativnih, odnosno izvaninstitucionalnih, izvora i načina komunikacije ovisi o brojnim čimbenicima koji su povezani s lokalnim društvenim, političkim, ekonomskim i kulturnim prilikama.

\section{ZAKLJUČAK ILI "VOŽNJA ZMAJEVIM KOČIJAMA"26}

Glavni mehanizam društvene promjene u procesima refleksivne modernizacije jest bujanje latentnih i nenamjeravanih sporednih učinaka i društvenih posljedica upravljačkih odluka. Nenamjeravane društvene posljedice rezultat su širenja tržišta, univerzalnih zakona i tehničkih revolucija, odnosno niza ekonomskih, političkih i kulturnih promjena globalnoga kapitalizma koje mijenjaju njegove vlastite temelje (Beck i sur., 2003.). Primijenjeno na medijski sustav, to znači da upravljačke odluke proizvode nenamjeravane posljedice $u$ medijskom sustavu, dok se istodobno razni društveni procesi prilagođuju i odvijaju kroz medije i medijski način funkcioniranja. Hrvatski se medijski sustav, dakle, mijenja pod učincima nenamjeravanih posljedica upravljačkih odluka te složenih vanjskih i unutarnjih prilika. Mediji istodobno zauzimaju sve važniju društvenu 
DRUŠ. ISTRAŽ. ZAGREB GOD. 21 (2012),

BR. 4 (118),

STR. $821-842$

BILIĆ, P.:

HRVATSKI MEDIJSKI.. ulogu, pa je tako nemoguće zamisliti političke izbore bez medija ili ekonomski uspjeh nekoga proizvoda bez reklamnoga i marketinškoga medijskog plana. Drugi društveni procesi, poput građanskih prosvjeda i izraza nezadovoljstva, također nalaze svoj izraz u raznim oblicima medijske komunikacije.

Refleksivnu modernizaciju vidimo prije svega $\mathrm{u}$ formalno-pravnom smislu promjene institucionalnog ustroja medijskoga sustava, koji je dodatno ubrzan adaptacijom i usklađivanjem s europskom pravnom stečevinom te utjecajima globalnih medijskih kompanija i potrošačke i popularne kulture. Izazov $\mathrm{u}$ teoretiziranju refleksivne modernizacije sastoji se $\mathrm{u}$ tome što se sustav koordinata mijenja (Beck i sur., 2003.). Upravo je to poanta razvoja hrvatskoga medijskog sustava, jer on kontinuirano izmiče koordinatama nacionalne države, što se vidi u stranom vlasništvu nad medijima, širenju potrošačkoga sadržaja i globalnom medijskom formatu razvijenih globalnih kulturnih industrija, uz vrlo malen utjecaj lokalnih kulturnih industrija, zakonodavnom usklađivanju sa standardima EU-a te upotrebom interneta i njime posredovanih globalnih medijskih platformi za korisnički generiran sadržaj. Refleksivna se modernizacija, dakle, očituje u procesima globalizacije i otvaranju medijskoga i telekomunikacijskoga tržišta, transnacionalnim procesima pristupanja EU-u i subpolitičkim procesima, dok se medijatizacija očituje u širenju i brojnosti oblika komunikacije i medija, posredovanju društvenih procesa i prilagodbi društvenih sfera na medijsko djelovanje.

Društveni su procesi po opsegu i složenosti daleko širi od formalno-pravnoga sustava koji čini okvir određenoga medijskog sustava. I u nacionalnom smislu unutar Europe taj sustav ostaje određen transnacionalnim procesima usklađivanja zakonodavstva. Mediji i komunikacija također se rabe na vrlo različite načine u vrlo različite svrhe. Zbog toga Giddens (1990.) smatra da ne možemo potpuno kontrolirati povijest i društveni život usmjeravajući ga po našoj kolektivnoj svrsi. Pošto su 1990-ih godina glavni problemi medijske politike bili odvajanje državne moći od medijskoga sustava, budući ispiti zrelosti društvenoga, a time i medijskoga, sustava u upravljačkome smislu bit će kontinuirani proces nalaženja ravnoteže i odgovarajućih mehanizama između kontrole i tržišnoga kaosa.

\section{BILJEŠKE}

1 Ovaj se članak temelji na istraživanjima financiranim u okviru Sedmog okvirnog programa Europske unije (FP7/2007-2013) pod ugovorom FP7-SSH-2009-244365 (MEDIADEM).

2 Zdenko Zeman (2004.), na primjer, razlikuje teorije modernizacije od teorija modernosti. Prve se odnose na strateška nastojanja kojima nemoderna društva mogu postati moderna. Ona se vežu uz političku, ekonomsku ili kulturnu sferu društvenoga života. Teorije moder- 
DRUŠ. ISTRAŽ. ZAGREB GOD. 21 (2012)

BR. 4 (118),

STR. $821-842$

BILIĆ, P.: HRVATSKI MEDIJSKI.. nosti se, s druge strane, odnose na pokušaje razumijevanja same naravi modernih društava.

${ }^{3}$ Medijske su dijete razni načini na koje korisnici kombiniraju izvore informacija i medija u jedinstveno komunikacijsko iskustvo. Vidi npr. Gustavo Cardoso (2006., 2008.).

${ }^{4}$ Ova je podjela prilagođena verzija klasifikacije koju uvode Zrinjka Peruško i Helena Popović (2008.). Autorice smatraju da je ona primjenjiva na sva postsocijalistička društva Srednje i Istočne Europe. U prvoj je fazi najvažnije bilo odvajanje medija od države i osiguranje njihove slobode i neovisnosti. Drugo razdoblje obilježava liberalizacija telekomunikacija i elektroničkih medija. Treće je razdoblje obilježeno EU integracijama i problemima primjene zakonodavstva.

${ }^{5}$ Broj ovisi o metodologijama bilježenja. Međutim, prema službenim podacima Hrvatske gospodarske komore, taj je broj u siječnju 2011 iznosio 876 tiskanih medija.

${ }^{6}$ http://www.e-mediji.hr/nakladnici/televizijski_nakladnici.php (1110-2011)

7 http://www.e-mediji.hr/nakladnici/radijski_nakladnici.php (11-10-2011)

8 http://www.hakom.hr/default.aspx?id=327 (11-10-2011)

${ }_{9}$ European Audiovisual Observatory (2010.), Television in 36 European States. Film, Television and Video in Europe, 2010 Edition, Vol. 1. Strasbourg.

10 Građanska javna sfera, prema Jürgenu Habermasu (1991.), nastaje u drugoj polovini 17. i na početku 18. stoljeća, između rastućega financijskog kapitalizma i državne moći, odnosno između sfere javnog autoriteta i privatnosti. Postupnim institucionalnim promjenama i konačnim "padom" u drugoj polovini 20. stoljeća zbog rasta moći medijskih kompanija javna je sfera postala mjesto manipulacije i "refeudalizacije".

$11 \mathrm{U}$ društvima prve moderne funkcionalna diferencijacija odvija se logikom progresivne specijalizacije društvenih funkcija s ciljem uspostavljanja bolje kalibracije sustava (Beck i sur., 2003.). U društvima druge moderne događaju se funkcionalne i legitimacijske krize koje zahtijevaju institucionalne promjene i promjene u procesima odlučivanja (Beck i sur., 2003.).

12 U izvještaju o napretku pregovora za 2010. godinu stoji: "[p]olitička volja i tehnički napori potrebni su za održavanje liberalizacije svih segmenata tržišta elektroničkih komunikacija kako bi se dobili opipljivi rezultati u smislu razvoja informacijskog društva te se promicalo natjecanje na radiotelevizijskom tržištu i nezavisnost javne radiotelevizije." http://www.eu-pregovori.hr/files/Izvijesce/Izvijesce EK_o_napretku_RH_2010.pdf (10-11-2011)

13 Za složen odnos HRT-a i komercijalnih televizija u procesu digitalizacije vidi Tena Perišin (2011.).

14 European Audiovisual Observatory (2010.).

15 Zakonom o elektroničkim medijima NN 153(09) i Zakonom o HRT-u NN 137(10)

$16 \mathrm{http} / / /$ ec.europa.eu/avpolicy/reg/history/historytvwf/index_en.htm (10-11-2011) 
DRUŠ. ISTRAŽ. ZAGREB GOD. 21 (2012), BR. 4 (118)

STR. $821-842$

BILIĆ, P.: HRVATSKI MEDIJSKI..

17 Za 2005. godinu vidi: http://ec.europa.eu/enlargement/archives/pdf/ key_documents/2005/package/sec_1424_final_progress_report_ hr_en.pdf (11-10-2011), za kasnije godine vidi: http://www.eu-pregovori.hr/ (11-10-2011)

18 Freedom House, Freedom of the press 2010, Table of global press freedom rankings. http://freedomhouse.org/images/File/fop/2010/FOTP2010 Global\&RegionalTables.pdf (11-10-2011)

$19 \mathrm{http}: / /$ www.freedomhouse.org/template.cfm?page =16 (11-10-2011)

$20 \mathrm{http}: / /$ www.internetworldstats.com/eu/hr.htm (11-10-2011)

21 Vidi Popović i sur. (2010.).

22 http://www.alexa.com/topsites/countries/HR (11-10-2011)

${ }^{23}$ Rabimo izraz web stranice za društvene mreže (eng. social network sites ili SNS) umjesto web stranice za društveno umrežavanje, jer je prema nekim istraživanjima utvrđeno da se takav tip mrežnih stranica najčešće rabi za već postojeće društvene mreže, a ne stvaranje novih (boyd i Ellison, 2007.).

24 Prema nekim procjenama kompanija je vrijedna 50 milijardi dolara, a u prvih devet mjeseci 2010. godine zaradila je 355 milijuna dolara neto prihoda. http://www.reuters.com/article/2011/01/06/us-facebookgoldman-idUSTRE70359V20110106 (11-10-2011)

25 Manuel Castells (2009.) nove oblike komunikacije zove masovna samokomunikacija, jer doseže globalne publike, proizvodnja sadržaja je samostalna, potencijalni primatelji se samostalno odabiru i poruke se samostalno šire preko mreže.

${ }^{26}$ Giddens (1990.) dinamiku modernizma opisuje zmajevim kočijama (eng. juggernaut), kojima možemo upravljati do određene mjere kao ljudska bića, ali koje stalno prijete da se otrgnu našoj kontroli i raspadnu na komadiće.

\section{LITERATURA} sand Oaks, New Delhi: SAGE Publications.

Beck, U. (1994). The reinvention of politics: Towards a theory of reflexive modernization. U U. Beck, A. Giddens i S. Lash (Ur.), Reflexive modernization: Politics, tradition and aesthetics in the modern social order (str. 1-55). Stanford: Stanford University Press.

Beck, U., Bonss, W. i Lau, C. (2003). The theory of reflexive modernization: Problematic, hypotheses and research programme. Theory, Culture \& Society, 20(2), 1-33. doi:10.1177/0263276403020002001

Beck, U. (2004). Moć protiv moći u doba globalizacije - nova svjetsko politička ekonomija. Zagreb: Školska knjiga.

Blokker, P. (2005). Post-communist modernization, transition studies, and diversity in Europe. European Journal of Social Theory, 8(4), 503-525. doi:10.1177/1368431005059703

boyd, D. M. i Ellison, N. B. (2007). Social network sites: Definition, history and scholarship. Journal of Computer-Mediated Communication, 13(1), 210-230. doi:10.1111/j.1083-6101.2007.00393.x 
DRUŠ. ISTRAŽ. ZAGREB GOD. 21 (2012)

BR. 4 (118),

STR. $821-842$

BILIĆ, P.: HRVATSKI MEDIJSKI..
Castells, M. (2009). Communication power. New York: Oxford University Press.

Cardoso, G. (2006). The media in the network society: Browsing, news, filters and citizenship. Lisabon: CIES - Centre for Research and Studies in Sociology.

Cardoso, G. (2008). From mass to networked communication: Communicational models and the informational society. International Journal of Communication, 2, 587-630.

Debatin, B., Lovejoy, J. P., Horn, A. K. i Hughes, B. N. (2009). Facebook and online privacy: Attitudes, behaviours, and unintended consequences. Journal of Computer-Mediated Communication, 15(1), 83-108. doi:10.1111/j.1083-6101.2009.01494.x

Gehl, R. W. (2010). A cultural and political economy of Web 2.0. A dissertation submitted to the Graduate Faculty of George Mason University in partial fulfillment of the requirements for the degree of Doctor of Philosophy of Cultural Studies. Posjećeno 11. 10. 2011. na: http://www.robertwgehl. org/text/gehl_diss_full.pdf

Gerhards, J. i Neidhardt, F. (1990). Strukturen und Funktionen moderner Öffentlichkeit: Fragestellungen und Ansätze. Berlin, Wissenschaftszentrum Berlin für Sozialforschung gGmbH (WZB). Posjećeno 11. 10. 2011. na: https://www.econstor.eu/dspace/bitstream/10419/.../1179 47946.pdf

Giddens, A. (1990). The consequences of modernity. Cambridge: Polity Press. Habermas, J. (1991). The structural transformation of the public sphere. Cambridge, MA: MIT Press.

Hjarvard, S. (2008). The mediatization of society: A theory of the media as agents of social and cultural change. Nordicom Review, 29(2), 105-134.

Krotz, F. (2007). Mediatisierung: Fallstudien zum Wandel von Kommunikation. Wiesbaden: VS Verlag.

Krotz, F. (2009). Mediatization: A concept with which to grasp media and societal change. U K. Lundby (Ur.), Mediatization: Concept, changes, consequences (str. 21-40). New York: Peter Lang Publishing.

Lash, S. i Urry, J. (1994). Economies of sign and space. London: SAGE.

Lash, S. (1994). Reflexivity and its doubles: Structure, aesthetics, community. U U. Beck, A. Giddens i S. Lash (Ur.), Reflexive modernization: Politics, tradition and aesthetics in the modern social order (str. 110-173). Stanford: Stanford University Press.

Livingstone, S. (2009). On the mediation of everything: ICA presidential address 2008. Journal of Communication, 59(1), 1-18. doi:10.1111/ j.1460-2466.2008.01401.x

Lundby, K. (2009). Introduction: 'Mediatization' as key. U K. Lundby (Ur.), Mediatization: Concept, changes, consequences (str. 1-18). New York: Peter Lang Publishing.

Perišin, T. (2008). Televizijske vijesti: u potrazi za vrijednostima. Medijska istraživanja, 14(2), 63-86.

Perišin, T. (2011). Kategorija 5. Medijska infrastruktura. U Z. Peruško, T. Perišin, M. Topić, G. Vilović i N. Zgrabljić Rotar (Ur.), Hrvatski medijski sustav prema UNESCO-ovim indikatorima medijskog razvoja (str. 135-163). Zagreb: Fakultet političkih znanosti. 
DRUŠ. ISTRAŽ. ZAGREB GOD. 21 (2012), BR. 4 (118)

STR. $821-842$

BILIĆ, P..: HRVATSKI MEDIJSKI..
Peruško-Čulek, Z. (1999). Demokracija i mediji. Zagreb: Barbat.

Peruško, Z. (2003). Medijska koncentracija: izazov pluralizmu u Srednjoj i Istočnoj Europi. Medijska istraživanja, 9(1), 39-58.

Peruško, Z. (2005). Televizija u Europi: zakonodavstvo, javne politike $i$ neovisnost - Hrvatska, Izvještaj za EUMAP. Budimpešta: Open Society Institute.

Peruško, Z. i Popović, H. (2008). Media concentration trends in Central and East Europe. U M. Sükösd i K. Jakubowicz (Ur.), Finding the right place on the map: Central and Eastern European media change in a global perspective (str. 165-189), Bristol, UK, Chicago, USA: Intellect Books.

Peruško, Z. (2009). Public interest and television performance in Croatia. Medijska istraživanja, 15(2), 5-31.

Popović, H., Bilić, P., Jelić, T. i Švob-Đokić, N. (2010). The case of Croatia - Background information report. U: Media policies and regulatory practices in a selected set of European countries, the EU and the Council of Europe, Izvještaj za MEDIADEM projekt (FP7-SSH-2009-A no. 244365). Posjećeno 11. 10. 2011. na: http://www.mediadem.eliamep. gr/wp-content/uploads/2010/05/BIR.pdf

Schulz, W. (2004). Reconstructing mediatization as an analytical concept. European Journal of Communication, 19(1), 87-101. doi:10.1177/02 67323104040696

Švob-Đokić, N. (2000). Tranzicija i nove europske države. Zagreb: Barbat.

Thompson, J. B. (1995). Media and modernity: A social theory of the media. Cambridge: Polity Press.

Tomić-Koludrović, I. i Petrić, M. (2007). From transitional to mixed society: Croatia between two modernizations. U: La questione adriatica $e$ l'allargamento dell'Unione europea (str. 127-161). Milano: Franco Angeli.

Zeman, Z. (2004). Autonomija i odgođena apokalipsa: sociologijske teorije modernosti i modernizacije. Zagreb: Hrvatska sveučilišna naklada.

Zgrabljić Rotar, N. (2003). Hrvatska medijska politika i javni mediji. Medijska istraživanja, 9(1), 59-75.

Županov, J. (2002). Od komunističkog pakla do divljeg kapitalizma: odabrane rasprave i eseji (1995-2001). Zagreb: Hrvatska sveučilišna naklada.

\section{Croatian Media System between Reflexive Modernization and Mediatization: Societal and Institutional Analysis}

Paško BILIĆ

Institute for International Relations, Zagreb

In the past two decades, Croatian society underwent significant social transformation and changes in all aspects of social life. Within that context, the media and communication system was rarely analyzed in an integrative way, or 
DRUŠ. ISTRAŽ. ZAGREB GOD. 21 (2012)

BR. $4(118)$

STR. $821-842$

BILIĆ, P.:

HRVATSKI MEDIJSKI.. as a central part of those processes. The goal of this paper is to analyze societal and institutional changes of the media system, social-political changes as well as market and technological development changes through a prism of two contemporary social meta-theories: reflexive modernization and mediatization. Therefore, data on a number of different media, ownership structures, audience reach and official EU accession negotiation documents are analyzed and presented. Some of the key changes of the media systems that are analyzed are institutional changes of the public broadcasting service, liberalization and privatization of the market as a changing boundary between private and public spheres, change of the dominant media content paradigm and consequently commercialization of media space, different European Union influences and the increasing role of the internet and new media in the media and communications system. The governance of the media system produces unintended consequences, while at the same time different social processes are being adapted to the media, granting them an increasingly important social role. Due to these changes, the system of coordinates of the national system is completely open to transnational processes.

Keywords: reflexive modernization, mediatization, public service, market liberalization, European Union 